\title{
ABORTO E CÉLULAS-TRONCO EMBRIONÁRIAS NA CAMPANHA DA FRATERNIDADE Ciência e ética no ensino da Igreja*
}

\author{
Naara Luna
}

Em 2008, o tema da Campanha da Fraternidade da CNBB foi "Fraternidade e defesa da vida". Este artigo analisa o manual produzido, situando essa campanha no contexto mais amplo da atuação da Igreja Católica na esfera pública. Defende-se a hipótese de que o lema "escolhe, pois, a vida" foi criado para fazer frente a duas questôes discutidas nos últimos anos pela sociedade brasileira: 1) o esforço do Ministério da Saúde e da Secretaria Especial de Políticas para as Mulheres para reinserir o aborto como problema de saúde pública, o que seria ocasião para alterar a lei vigente; 2) a produção de embriōes humanos na reprodução assistida e o uso dos excedentes em pesquisas para a produção de células-tronco. ${ }^{1} \mathrm{~A}$ pesquisa com células-tronco e

* Agradeço a leitura e comentários de Edlaine de Campos Gomes e Rachel Aisengart Menezes.

Artigo recebido em abril/2009

Aprovado em junho/2010 o debate sobre a legalização do aborto são processos independentes liderados por atores sociais distintos (no primeiro caso, a comunidade científica, no segundo, o movimento de mulheres) que foram conjugados por incidirem na intervenção sobre embriōes e fetos humanos. A Igreja Católica tem sido um ator fundamental em ambas as controvérsias e as aglutinou no tema da Campanha da Fraternidade (CF) de 2008, impondo a força de um discurso religioso até então hegemônico no debate público. Baseando-se no manual elaborado pela CNBB que serviu de recurso didático para a campanha, este texto enfoca as representações sobre feto e embriōes e a argumentação usada para lhes negar ou lhes atribuir a condição de pessoa. O conceito de "vida" é peça-chave nessa retórica, que desliza entre o discurso científico e o religioso. $\mathrm{O}$ esforço de situar as polêmicas sobre o aborto e a pesquisa com células-tronco embrionárias no contexto da atuação da Igreja no espaço público remete à proposta de 
Birman de "observação dos entrelaçamentos, dos confrontos e das configurações de que o religioso participa como um ator entre outros da sociedade" (2003, p. 12). Reconstituir a atuação pública da Igreja é essencial para fazer as conexóes entre as demandas do documento e seu contexto amplo.

\section{$O$ contexto}

Desde o grande aggiornamento promovido no contexto do Concílio Vaticano 2 no início da década de 1960, a Igreja tem enfrentado de diferentes formas as consequências dos processos de modernização, ora se aliando a tendências mais conservadoras, ora assumindo linhas modernizantes (Berger, 2001). Se o concílio implicou modernização litúrgica e abertura para o diálogo inter-religioso, posturas conservadoras foram afirmadas em outras esferas. Um dos exemplos está na Encíclica Humanae Vitae do Papa Paulo VI em que a Igreja mantém a posição de limitar os meios de contracepção aceitos aos métodos de abstinência periódica, embora reconheça as necessidades do casal em planejar sua família (Pierucci, 1978). A Igreja estaria respondendo de diversas formas ao processo de secularização, uma tendência modernizadora que empurra a religião para o espaço privado (cf. Berger, 1985).

Se o processo de secularização restringe o papel da religião à formação moral no âmbito privado, no Brasil é notável a presença da Igreja Católica na esfera pública tanto na intervenção acerca de questôes sociais - a reforma agrária, entre outras como em tópicos que seriam referidos à vida privada, com respeito à vivência da reprodução e da sexualidade. Contudo, a atuação da Igreja Católica quanto a questôes sociais é marcada por ambiguidades, pois adota um discurso progressista voltado para certos problemas, e apoia posiçôes conservadoras do Vaticano no tocante à reprodução e à sexualidade (Rosado-Nunes, 2002). Pretende-se delinear aqui cenários de atuação da Igreja Católica no espaço público brasileiro, fazendo referência às pastorais promovidas pela $\mathrm{CNBB}$ e também à ação intersticial de associações não pertencentes à Igreja, mas denominadas católicas, como as uniōes de magistrados católicos. Membros dessas associações apresentam papel destacado em ações no contexto do Judiciário e no parlamento.

A CNBB é uma das principais entidades da Igreja Católica e tem atividade pública destacada. O portal da $\mathrm{CNBB}^{2}$ apresenta uma maioria de pastorais voltadas para temas sociais, que se dedicam a aspectos externos à organização eclesiástica com predomínio de tarefas de serviço e de organização de grupos marginalizados. ${ }^{3}$ A minoria ocupa-se de questôes eclesiásticas. A Pastoral Familiar fica em posição liminar, na articulação entre o espaço privado do grupo doméstico e o espaço público.

Destacam-se tensóes entre uma agenda comprometida com causas ditas progressistas e a atuação de pastorais que articulam a esfera privada ou familiar com questões públicas. A Pastoral Familiar (Comissão Episcopal Pastoral para a Vida e a Família) conjuga aspectos referentes à formação católica no âmbito privado e a intervenção no âmbito público, representando a família como o grupo social que une a formação da fé nessas duas esferas. Tal se verifica nos temas dos eventos divulgados na página da pastoral: "a família formadora dos valores humanos e cristãos" e "a defesa da família”, com menção ao papel dos pais como primeiros catequistas e à relevância da espiritualidade conjugal e familiar. ${ }^{4}$ Na página da Pastoral Familiar, encontram-se campanhas referentes à adoção, à contracepção, sobre a dignidade da pessoa e em defesa da vida humana, isto é, contra o aborto, o que inclui a promoção do "dia do nascituro". Há uma ligação de hipertexto (link) com a Comissão de Bioética da CNBB e a "Declaração sobre exigências éticas em defesa da vida”. Essa pastoral alia a ênfase tradicional de trabalho catequético na família com preocupações de ordem reprodutiva formuladas segundo a orientação da bioética de linha católica.

A Pastoral da Aids, embora enfoque temas da esfera privada no tocante à vivência da sexualidade, enfatiza as políticas públicas de saúde e a superação da discriminação, com predomínio do aspecto público (Seffner et al., 2008). Outra comissão estratégica é a Pastoral da Criança, uma organização considerada progressista por sua atuação de assistência às famílias e educação a fim de superar a mortalidade infantil, mas que está engajada nas campanhas pró-vida e antiaborto (Anjos, 2007). 
A atuação da Igreja Católica no espaço público não se restringe às suas pastorais, mas chega a instâncias do Legislativo, do Executivo e do Judiciário. Com respeito a condutas consideradas de foro íntimo, questões referentes à saúde reprodutiva e à liberdade sexual, exemplificadas por contracepção, técnicas de reprodução assistida, aborto e direitos dos homossexuais, a Igreja Católica não se limita à orientação pastoral de seus fiéis, mas tem representado um poderoso agente de pressão nas instâncias públicas (Rosado-Nunes, 2002). Em particular, com respeito ao aborto, os que participam do debate sobre sua legalização no Brasil reconhecem que a enorme influência dessa instituição não se restringe à esfera íntima relativa a valores pessoais que formam a posição acerca dessa prática (cf. Cavalcante e Xavier, 2006). No debate constitucionalista sobre a legalização do aborto no Brasil, juristas defendem o princípio de laicidade do Estado, recusando a predominância do catolicismo como justificativa para adoção de medidas legislativas que endossem as concepções morais católicas (Sarmento, 2006). Identifica-se a ação da Igreja Católica e de seus representantes como grupo de pressão no Legislativo (Rocha, 1996) e no Judiciário (Fernandes, 2007). Maria Isabel Baltar Rocha (1996) destaca quatro atores sociais no Congresso Nacional no tocante ao debate de projetos de lei sobre aborto: a Igreja Católica (desde 1949), a categoria médica (segunda metade da década de 1960), o movimento feminista (início dos anos de 1980) e os evangélicos (segunda metade dos anos de 1980). Na imprensa, é frequente a veiculação das posiçôes da Igreja sobre o aborto (cf. Melo, 1997). Identificou-se um grupo de pressão religioso nos debates legislativo e jurídico das pesquisas com células-tronco embrionárias (Cesarino, 2006; Luna, 2007a).

No Judiciário, observam-se duas frentes de atuação. Primeiro, a ação de inconstitucionalidade (ADI) 3.510 contra o artigo $5^{\circ}$ da lei de biossegurança que autoriza o emprego de embriōes excedentes do tratamento de reprodução assistida para a extração de células-tronco, movida em maio de 2005. $\mathrm{Na}$ ação no STF, a CNBB foi representada como parte interessada do processo. Em abril de 2007, na audiência pública da ADI 3.510 com especialistas, a CNBB foi a única entidade a indicar expositores, segundo o relator, ministro Carlos Ayres Britto (cf. Luna, 2007a). A imprensa acusou o autor da ação de ser católico fervoroso e de ter convocado cientistas alinhados. ${ }^{5} \mathrm{O}$ julgamento ocorreu entre março e maio de 2008, pouco depois do encerramento da CF 2008. A imprensa chamou de juiz católico ${ }^{6}$ o ministro que pediu vistas do processo, e comentou sobre associaçôes de juristas católicos. ${ }^{7}$ Com respeito à atuação de magistrados, reconhece-se não a interferência direta da instituição, mas a tensão entre o catolicismo como formador de valores e o vínculo dessas associaçôes e indivíduos à Igreja Católica.

Uma segunda frente de atuação está na intervenção de representantes da Igreja nas decisões jurídicas com respeito à interrupção da gestação em casos de anencefalia (anomalia incompatível com a vida), ao interporem recursos contra concessōes de autorização (cf. Fernandes, 2007). ${ }^{8}$ Em junho de 2004, a Confederação Nacional dos Trabalhadores na Saúde ajuizou no Supremo Tribunal Federal a Arguição de Descumprimento de Preceito Fundamental (ADPF) no 54 que requeria assegurar às gestantes de anencéfalo o direito de se submeterem à antecipação terapêutica do parto e ao médico, o direito de realizar o procedimento, uma vez atestada a anomalia por profissional habilitado, sem necessidade de autorização prévia judicial ou de qualquer forma de permissão específica do Estado (Fernandes, 2007). O relator do processo, ministro Marco Aurélio Mello deferiu a liminar, mas o plenário do Supremo não a referendou. Em 2005, o STF aprovou a admissibilidade da ADPF 54. Entre agosto e setembro de 2008 , foram realizadas audiências públicas com representantes do governo, inclusive $\mathrm{o}$ ministro da saúde e a presidente do Conselho Nacional de Direitos da Mulher, e da sociedade civil, o que incluiu movimentos feministas, movimentos pró-vida, médicos, e uma sessão específica com representantes de entidades religiosas. ${ }^{9}$ Alguns especialistas foram expositores em ambas as audiências públicas de instrução da ADI 3.510 (sobre uso de embriōes em pesquisa) e da ADPF $54 .^{10}$

Quanto à ação no Legislativo, Santin (2000) fez um estudo do grupo de pressão católico, ao analisar a atuação da pastoral familiar da CNBB e do grupo parlamentar católico na tramitação do PL20/91, projeto para regulamentar o aborto legal 
no Brasil, previsto no código penal desde 1940. Descrevendo a votação na assembléia legislativa do Rio Grande do Sul do projeto que dispunha sobre o atendimento nos hospitais da rede pública de saúde dos casos de aborto permitidos no Código Penal Brasileiro, Kalsing (2002) identifica na bancada o grupo parlamentar católico, vinculado tanto à Igreja Católica como ao grupo de pressão "Movimento em Defesa da Vida", e registra o engajamento dos parlamentares evangélicos. Investigaçôes mais recentes sobre valores religiosos revelam a atuação de parlamentares reunindo os deputados católicos afinados com as diretrizes da Igreja e a bancada evangélica na tramitação no Congresso Nacional de projetos de lei referentes ao aborto (Gomes, 2009), à criminalização da homofobia, pela união/parceria civil (mais conhecido como casamento gay) (Natividade e Lopes, 2009) e com respeito à eutanásia (Menezes, 2009). Trata-se do debate sobre os direitos individuais. A religião aparece ora como esfera englobante, que pretende regulamentar tais questôes na esfera pública, ora como esfera englobada, que instrui seus adeptos em seus valores pessoais. A Igreja Católica tem atuado para proporcionar a formação condizente com sua doutrina e como poderoso grupo de pressão.

O governo federal tem tomado iniciativas para ampliar os permissivos do aborto legal por intermédio da Secretaria Especial de Políticas para as Mulheres (SPM) e do Ministério da Saúde. Em levantamento dos projetos de lei no Congresso Nacional concernentes a aborto e eutanásia, Gomes e Menezes (2008) destacam três situaçōes críticas recentes com respeito ao aborto: a edição da Norma Técnica para Prevenção e Tratamento de Agravos Decorrentes da Violência Sexual (do Ministério da Saúde em 1999, revisada em 2005); a instalação da comissão tripartite de revisão da legislação punitiva ao aborto, com respectiva audiência pública na Comissão de Seguridade Social e Família do Congresso Nacional em 2005; ${ }^{11}$ a audiência pública sobre aborto em junho de 2007 na mesma comissão. A iniciativa da comissão tripartite procedeu da SPM. ${ }^{12}$ Além da revisão da norma técnica, o Ministério da Saúde tomou iniciativas para situar o aborto como problema de saúde pública: a promoção de ampla pesquisa de revisão de publicaçōes científicas sobre aborto no Brasil com esse enfoque nos últimos vinte anos. ${ }^{13}$

Este artigo se detém em duas questôes que foram relacionadas em virtude da pressão de movimentos pró-vida ligados à Igreja Católica: o aborto e a pesquisa com células-tronco embrionárias. A junção deu-se na Campanha da Fraternidade promovida pela CNBB no ano de 2008, cujo tema era "Fraternidade e defesa da vida". Além de orientação pastoral aos fiéis, a Igreja pretende obstruir a tentativa de ampliação dos permissivos para o aborto legal, a reprodução assistida e a produção de célulastronco embrionárias. Tal influência é perceptível não só no âmbito legislativo com a presença nos parlamentos federais e estaduais, onde tramitam os projetos de lei, e nas audiências públicas (Cesarino, 2006; Gomes, 2009; Cunha, 2007, Kalsing, 2002), mas também nas decisōes do Judiciário (ADPF 54, ADI 3.510). Representantes da CNBB denunciam as políticas do governo federal (gestão Lula): segundo o assessor da Comissão de Vida e Família, "O aborto no Brasil só não está legalizado oficialmente, mas o Estado tem feito uma política de aborto e de amparo às que querem abortar". ${ }^{14}$ Esse contexto situa a Campanha da Fraternidade de 2008, cujo manual é analisado a seguir.

\section{Fraternidade e defesa da vida}

A Campanha da Fraternidade (CF) de 2008 foi lançada com tema "Fraternidade e defesa da vida" e o lema "Escolhe, pois a vida" (Deuteronômio 30.19). A introdução do texto-base da CF 2008 (\$ 2 , p. 26) apresenta a relação de outras campanhas em que esse assunto esteve sob enfoque. ${ }^{15}$ Nos últimos anos, várias vezes a palavra "vida" foi incluída nos temas ou lemas da campanha, porém, no ano de 2008, o emprego do termo esteve diretamente ligado a duas questóes específicas: o combate ao aborto e a rejeição à pesquisa com células-tronco extraídas de embrióes humanos. Embora o textobase não tenha se restringido a esses tópicos, a "defesa da vida" e o objetivo geral de "levar a Igreja e a sociedade a defender e promover a vida humana desde a sua concepção até a sua morte natural" (\$12, p. 31), houve claramente ênfase maior na vida 
a partir da fecundação, independentemente se na etapa intrauterina ou em laboratório na fertilização in vitro. A seguir, descreve-se a estrutura do manual e as principais temáticas abordadas. Faz-se uso da metodologia de análise categorial: a partir do exame do texto-base da campanha, há o recorte e a seleção das categorias centrais que aparecem no material, as quais são utilizadas para estabelecer classificações, agrupando elementos, ideias ou expressóes em torno de um conceito - procedimento típico de análise em pesquisa qualitativa (Gomes, 1994).

$\mathrm{Na}$ ficha catalográfica, as palavras-chave são: aborto, Campanha da Fraternidade, conversão, eutanásia, fraternidade, vida, vida - aspectos religiosos - Cristianismo. Com 360 páginas o manual é composto por um texto-base da campanha e materiais destinados a uso em rituais ou em educação. A porção mais longa é o texto-base (124 páginas), acompanhado da apresentação da Campanha e de orientaçôes sobre seu histórico. No material para uso litúrgico, há o hino da $\mathrm{CF}$, a oração da $\mathrm{CF}$, rituais para Via-Sacra (a CF ocorre na Quaresma, da quarta-feira de cinzas até o domingo de Páscoa), vigília eucarística e celebração da misericórdia. $\mathrm{O}$ item "Fraternidade viva" contém quatro estudos. Há, ainda, cinco folhetos quaresmais para os domingos. Alguns itens mesclam o caráter educativo e de celebração: fraternidade nos círculos bíblicos; círculos bíblicos ecumênicos; encontros catequéticos com crianças e adolescentes; jovens na CF. Na terceira estrofe do hino da CF-2008, consta: "Com tristeza vejo a vida desprezada,/ Nos meus filhos e em toda a natureza./ Me entristece tantas vidas abortadas,/ Dói em mim a violência e a pobreza". Trechos da oração da CF são dignos de nota: "Junto aos avanços, presenciamos tantas ameaças à vida”; e mais adiante: "que o compromisso de nossa fé nos leve a defender e promover a vida no seu início, no seu crescimento e também no seu declínio". ${ }^{16}$ A oração termina com apelo a Maria: "Maria, Mãe da vida, que protegeu e acompanhou seu Filho, da gestação à ressurreição, interceda por nós”. O hino e a oração explicitam a defesa da vida desde a concepção e a crítica ao aborto.

O texto-base da CF-2008 será a fonte principal da presente argumentação por fundamentar os outros materiais contidos no manual. Os principais pontos de ataque aparecem na Introdução: a CF2008 "expressa a preocupação com a vida humana, ameaçada desde o início por causa do aborto até sua consumação em vista da eutanásia” (\$3, p. 26). Afirmam-se valores filosóficos com fundamentação teológica: "o encontro com Cristo é o ponto de onde partimos para reconhecer plenamente a sacralidade da vida e a dignidade da pessoa humana" (\$11, p. 30, grifos meus). Após a introdução, o texto-base divide-se em três partes - "Ver: entre a cultura da vida e a cultura da morte"”, "Julgar: Deus indica o caminho da vida" e "Agir: em defesa da vida". O método ver-julgar-agir, característico das correntes liberacionistas da Teologia latino-americana, estabelece três passos: "ver" refere-se ao diagnóstico da realidade social; "julgar” faz-se a partir da Bíblia e da tradição da Igreja; "agir" traça metas de ação para transformar a realidade (Angelozzi, 2008).

A primeira parte fundamenta-se em estudos sociológicos, históricos e da bioética e abrange seis seçôes (pp. 33-82): "I. A pessoa humana e a cultura da morte"; "II. Vida, afetividade e sexualidade"; "III. A vida não nascida"; "IV. A vida, o sofrimento e a morte"; "V. A sociedade e as ameaças à vida"; "VI. As ameaças à vida e o meio ambiente". A primeira seção aborda a articulação dos fatores que favorecem a cultura da vida e os que levam à morte (\$17 a 54, pp. 34-46), cujo texto mais extenso se encontra na subseção 4: "Os desafios da ciência e das novas tecnologias” (pp. 41-45). A posição do texto com respeito à ciência é ambivalente: "As ciências e as novas tecnologias são instrumentos poderosos tanto de auxílio como de ameaça à vida" (\$46, p. 42). Ciência e técnica são pontos preferenciais de crítica pelo texto, com exemplos sobre o "tipo de pesquisa que desrespeita os direitos humanos" (p. 45): a extração de células-tronco por demandar a destruição de embriōes.

Nesta parte do manual, as seções II e III são mais relevantes para a nossa perspectiva. A primeira revela como questóes voltadas para a reprodução humana estão no cerne do debate: "Alguns dos temas mais importantes para a defesa da vida humana na atualidade se referem a questôes que afetam a reprodução humana, como o aborto e a reprodução assistida (bebê de proveta)" ( $\$ 55$, p. 47). Aborda-se também o tema da gravidez inde- 
sejada, defendendo o "método natural" de contracepção. A seção III divide-se em sete subseçôes, cujos títulos evidenciam a abrangência do enfoque sobre embrião e feto, gerados ou não em laboratório, seu desenvolvimento e destino: 1) o aborto (sobre a questão legal); 2) o aborto e a saúde pública; 3) o aborto como "mal necessário" (contra a argumentação feminista); 4) o financiamento externo para liberação do aborto (conferências sobre população, aborto e controle populacional); 5) o desejo de ter filhos e a reprodução assistida (o bebê de proveta); 6) as células-tronco (contra a pesquisa que demande destruir embrióes); 7) eugenia, seleção de sexo e projeto dos pais em relação aos filhos (contra o diagnóstico genético préimplantação: PGD).

A centralidade do debate sobre o aborto e o estatuto do embriāo humano para argumentação de defesa da vida revela-se na análise da extensão dos itens dessa parte do manual. Quinze páginas compōem a seção III ("A vida não nascida"), a qual, como vimos, centra-se nos temas aqui enfocados. Trata-se da seção mais ampla, quando comparada às outras: treze, seis, oito, duas e cinco páginas, respectivamente às seçôes I ("A pessoa e a cultura da morte"), II ("Vida, afetividade e sexualidade"), IV ("A vida o sofrimento e a morte", que trata do sentido da morte e do sofrimento, incluindo temas do suicídio e eutanásia), V ("A sociedade e as ameaças da vida", que discorre sobre a pobreza) e VI ("As ameaças à vida e ao meio ambiente, que trata do problema ecológico e da demografia). A tendência de dissertar mais longamente sobre as questōes relacionadas com o aborto e a fase embrionária mantém-se ao longo do documento.

A segunda parte principia com a concepção teológica segundo textos bíblicos e segue com documentos do magistério da Igreja. Divide-se nas seçōes: "I. A vida, dom de Deus"; "II. O encontro com Cristo nos convida a escolher a vida"; "III. A vida no Espírito e a Igreja" e "IV. Discernindo entre os caminhos da vida e os caminhos da morte".

A quarta seção, a mais relevante para a análise aqui empreendida, é composta das subseções: 1) Discernimento sobre a pessoa humana; 2) Discernimento diante dos avanços da ciência; 3) Discernimento diante da esterilidade conjugal (contra a "reprodução artificial"); 4) Discernimento diante da gestação indesejada (contra o aborto); 5) Discernimento diante da manipulação do embriāo; 6) Discernimento diante da vida afetivo-sexual; 7) Discernimento diante da pobreza; 8) Discernimento diante da violência; 9) Discernimento diante do sofrimento (busca de sentido para o sofrimento); 10) Discernimento diante da morte (contra a eutanásia e seu oposto, a obstinação terapêutica). Pela divisão dos temas, fica patente a ênfase no questionamento à ciência e na problemática que cerca a reprodução humana e sexualidade, em particular o estatuto de pessoa do feto e do embrião. Mesmo o item sobre a pobreza remete à reprodução: "a contracepção e o aborto não podem ser considerados soluções para os problemas decorrentes da pobreza” (\$223, p. 106).

A terceira parte do texto-base apresenta propostas práticas para a "promoção humana" em suas seçōes aqui abreviadas: a exigência da caridade; conscientizar e agir; açōes (da comunidade) para defender a vida; a transformação das estruturas; coleta da solidariedade e destinação do fundo nacional de solidariedade. Em seu intuito de fomentar práticas, é a parte mais diversificada no que diz respeito à "defesa da vida". Uma porção menor das açōes remete à reprodução humana. Destacam-se a proposta de cursos de pós-graduação em Bioética Personalista, e de bioética no currículo de graduação ( $\$ 267$, p. 123), além de uma postura próativa diante dos meios de comunicação ( $\$ 270$, p. 124). Entre as açôes da comunidade, há um item para "acolher a gestante em dificuldade e seu filho" (\$272-273, pp. 124ss), e nas pastorais propõe-se fortalecer o Comitê de Bioética da CNBB, aprofundando o estudo da bioética personalista entre pessoas de vários níveis na Igreja (\$280, p. 127). Muitas propostas de "transformação das estruturas" voltam-se para políticas públicas (\$287, p. 129): demandar o cumprimento do Artigo $5^{\circ}$ da Constituição que garante a inviolabilidade do direito à vida; ação junto a parlamentares para impedir a aprovação de projetos de lei que descriminem o aborto $^{17}$; "lutar por uma legislação que combata a praga $[s i c]$ do congelamento de embrióes nas clínicas de reprodução assistida"; assegurar o respeito à objeção de consciência. Salienta-se a ênfase em 
bandeiras referentes à disseminação da bioética de linha católica (bioética personalista), o grupo de pressão legislativo tanto com respeito ao aborto como à reprodução assistida, e a interpretação constitucional da inviolabilidade do direito à vida desde a concepção.

No restante do manual, observam-se propostas de estudos e celebraçôes. O item "Fraternidade Viva" reproduz a estrutura "ver, julgar, agir". Dos nove estudos, há "o direito de nascer bem", que é específico sobre reprodução e aborto, mas a defesa da vida desde a concepção até a morte natural e a crítica ao aborto e à eutanásia são citados em vários outros. Para celebraçôes, esses tópicos surgem na oração e no hino da CF-2008. Dos quatro encontros com estudo e celebração da "Fraternidade nos círculos bíblicos", em três menciona-se a defesa da vida, inclusive das crianças não nascidas, e se usa o aborto como fato negativo. Dos quatro encontros de estudo e celebração nos "Círculos bíblicos ecumênicos", o último menciona entre as "maldiçōes" da sociedade "a falta de apoio às gestantes pobres, $\mathrm{o}$ aborto e mortalidade infantil” (p. 261). O terceiro, dos quatro "Encontros catequéticos com crianças e adolescentes", aborda a ameaça à vida antes do nascimento e os perigos da ciência. Um dos quatro estudos "Jovens na CF" enfoca "vida, afetividade e sexualidade".

$\mathrm{Na}$ impossibilidade de uma análise extensa da totalidade do texto-base, destacam-se a seguir trechos mais significativos que revelem as categorias centrais, cada um representando temática específica.

\section{A noção de pessoa como individuo}

O texto-base defende a vida da pessoa humana e pretende demonstrar claramente que tipo de pessoa é essa: "A segunda experiência constitutiva de nossa pessoa é a percepção do próprio 'eu', da própria individualidade e da própria dignidade. Eu não me confundo com os outros, eu não sou parte de minha mãe ou do meu pai” (\$21, p. 35). Essa passagem revela a representação de pessoa como indivíduo peculiar à cultura ocidental moderna, o ser moral, independente, autônomo e essencialmente não social que veicula os valores supremos e ocupa o primeiro lugar na ideologia ocidental moderna do ser humano e da sociedade (Dumont, 1992). Trata-se do sujeito kantiano autocontido e dotado de dignidade intrínseca (Fagot-Largeault, 2004). Essa noção de indivíduo será usada no texto como argumento para recusar qualquer tipo de aborto ou manipulação do embrião, mesmo aquele gerado fora do útero, no contexto de laboratório.

\section{Vida: seu início e o direito à vida}

Outra categoria central é a noção de vida. A distribuição em tópicos, segundo a extensão de texto dedicado aos diferentes itens, evidencia que a ênfase do texto recai na defesa da "vida" anterior ao nascimento, seja a vida do feto durante a gravidez, seja o embrião gerado e mantido em laboratório. Destaca-se a definição de início da vida, equiparada ao início da condição de pessoa humana, ou "o novo indivíduo da espécie humana" no momento da fecundação: "É impossível negar que, com a união dos 23 cromossomos do pai com os 23 cromossomos da mãe, surge um novo indivíduo da espécie humana". E prossegue: "É um novo indivíduo que apresenta um padrão genético e molecular distinto, pertencente à espécie humana e que contém em si próprio todo o futuro de seu crescimento" (\$74, p. 53 , grifo original). Esse trecho, além de reforçar a representação de pessoa como indivíduo autônomo, apresenta dados do essencialismo genético: tratase de um "padrão genético e molecular distinto", o que exemplifica a genetização da pessoa (Salem, 1997). Esses valores naturalistas na descrição de embrióes e fetos como seres humanos essenciais em termos biológicos são reiterados ao longo do textobase tal como se vê na expressão acima que define o indivíduo pela união dos cromossomos dos pais. $\mathrm{Na}$ cosmologia ocidental moderna, o naturalismo consiste na valoração nova e radical da realidade física do mundo apreensível pela razão humana (vista ela própria como natural) e oposta à preeminência cristã tradicional da sobrenatureza e da transcendência moral (Duarte et al., 2006, p. 22). ${ }^{18}$ Nesse ponto, aponta-se a flagrante contradição no discurso encetado no documento, que necessita apelar para a base biológica como signo dos valores cristãos transcendentes. A atribuição de valores 
transcendentes a entes biológicos já foi examinada com respeito ao estatuto dos embriōes:

Nesse campo, onde se debatem as definiçôes legítimas de vida e pessoa, tenta-se fundamentar a existência desses atributos metafísicos essenciais na Natureza, ou em sua versão moderna para os seres vivos - a Biologia. Questôes discutidas muito antes da emergência da Biologia como ciência necessitam do calço da "ciência da vida” para alcançar o estatuto de verdade. Ao contrário da expectativa iluminista que o avanço do conhecimento científico solapasse questôes religiosas e metafísicas, estas ressurgem no debate, travestidas nos conceitos biológicos, os últimos refúgios da transcendência (Luna, 2007b, p. 434).

Conforme analisado em documentos do magistério católico (Luna, 2002), o trecho citado do texto-base exemplifica a relação tensa do diálogo entre a doutrina católica e o saber científico: aquela necessita apropriar-se seletivamente do discurso biológico para fazer valer seus argumentos, mesmo que questione os avanços da ciência como faz diversas vezes no manual. Não se recorre apenas à ciência, mas também à legislação: o artigo $5^{\circ}$ da Constituição Federal Brasileira é invocado por garantir a "inviolabilidade do direito à vida" ( $\$ 90$, p. 59), interpretada pela Igreja como tendo início na concepção, e assim argumentar contra qualquer tipo de aborto ou de intervenção em embriōes, independentemente do contexto. $\mathrm{Na}$ segunda parte do texto, que descreve a fundamentação teológica, a vida é definida como dom de Deus (p. 85).

\section{O aborto}

O presente artigo defende a tese de que o principal alvo do texto-base são as práticas ou os permissivos para o abortamento. Com o argumento de proteger crianças indefesas, o documento ataca qualquer tipo de intervenção para interromper a gravidez: "todo aborto provocado nega a uma criança $[$ sic] o direito de viver quando ela ainda não pode se fazer ouvir” (\$77 p. 54). No tocante aos dois casos previstos no Código Penal em que o aborto não é punido - para salvar a vida da mãe e em gestação decorrente de estupro - a posição da Igreja se mantém contrária. Com respeito ao aborto para preservar a vida da gestante, argumenta-se que "atualmente, com os recursos da medicina, tal situação é uma grande exceção, porque é possível salvar a criança e a mãe, mesmo em casos de partos bastante prematuros" ( $\$ 78$, p. 54 ). Salienta-se mais uma vez a ambivalência do documento com respeito à ciência: o recurso técnico, criticado como eugenia no diagnóstico fetal que indicaria o aborto no caso de malformaçôes (\$79, p. 55), é louvado quando se trata dos recursos da medicina para preservar a gravidez. Quanto à gravidez decorrente de estupro, considera-se o aborto uma nova violência contra a mãe, e que a maioria das mães, passada a rejeição, vai amar seu filho (\$78, p. 55). Pretendendo defender as mulheres, o documento afirma que o aborto seria outra violência contra a vítima de estupro (\$78, p. 55). É nítida a hierarquização entre qual pessoa deve ser respeitada em sua dignidade: $\mathrm{o}$ feto antes que a gestante.

\section{Embrióes gerados em laboratório e a pesquisa com células-tronco}

O texto-base critica a "cultura de direitos" no tocante às técnicas de reprodução assistida, ao fazer a interferência direta na reprodução, a fim de efetivar o "direito ao filho". Questionam-se as técnicas de fertilização in vitro, por propiciarem a prática de eugenia na seleção de embriōes e por facilitarem a manipulação desses entes em experimentos (p. 63), bem como por permitirem a produção de embriōes excedentes que não são transferidos para o útero e devem ser congelados ( $\$ 105$, p. 66). Na terceira parte, consta a recomendação para se "lutar por uma legislação que combata a praga [sic] do congelamento de embriōes nas clínicas de reprodução assistida" (p. 129). Com respeito à experimentação em embrióes excedentes, no caso para produção de células-tronco, o documento rebate a inviabilidade dos embrióes criopreservados com exemplos de nascimento após muitos anos de congelamento (\$105, p. 66), além de questionar a necessidade de destruir embriōes $(\$ 104$, p. 65$)$, denunciar que "cientistas exageraram publicamente a promessa 
das células-tronco embrionárias" ( $\$ 104$, p. 65) e apontar o risco do desenvolvimento de tumores e rejeição (\$103, p. 64). Aqui o foco de interesse é o embrião de laboratório: evitar sua geração e impedir qualquer manipulação como o congelamento e o uso em pesquisas, questionando-se o alcance das últimas.

\section{A reconstrução seletiva da história do aborto na doutrina católica}

O apelo à sua tradição perene é um recurso retórico para autolegitimar uma instituição que se pretende una há dois milênios: "sempre se pensou assim". Constata-se a seletividade na narrativa da história do pensamento doutrinário apresentada no texto-base. Afirma-se que "desde cedo, também os cristãos se posicionaram contra o aborto, reconhecendo a dignidade do embrião humano" ( $\$ 194$, p. 97). Os estudos de Jane Hurst (2000) mostram o contrário, com a condenação tardia, apenas no século XIX, do aborto em todas as fases da gravidez. Antes prevalecia a teoria da hominização tardia do "feto" (não existia tal categoria então) baseada em São Tomás Aquino. Tal posição é explicada como decorrente de "questões de conhecimento biológico": "São Tomás Aquino considera que existe o aborto a partir do momento que a alma entra no feto. Porém segundo seus conhecimentos de biologia reprodutiva, isso não aconteceria logo no momento da fecundação" (\$194, p. 97). Tal interpretação pelo documento revela dois pontos distintos: o primeiro refere-se à cosmovisão ocidental moderna que busca na natureza o fundamento da realidade e de prescrições da ordem social (Laqueur, 1992), origem das crenças naturalistas de hoje, por isso a teologia antiga não seria falha ao atribuir a entrada da alma em período posterior à concepção, apenas seus conhecimentos seriam insuficientes. Em conformidade com a cosmologia ocidental moderna, a doutrina da Igreja para se atualizar procura a coerência entre a "base biológica" (o momento da concepção) e a realidade espiritual. O segundo ponto diz respeito à qual tradição da Igreja se escolhe invocar ou omitir, impondo à teologia do período escolástico concepçôes de natureza pertinentes à cosmovisão atual (cf. Luna, 2002).
Aborto: a critica à liberdade de escolha e o direito à resistência

A seção IV da segunda parte apresenta a fundamentação teológica e filosófica com respeito à esterilidade conjugal (contra a reprodução assistida), sobre a gestação indesejada e a manipulação do embriāo. Quanto ao aborto, o texto-base admite que "não se pode negar que o aborto clandestino traz maior risco para mulher", mas "não permite sua admissão como um 'mal menor"” (\$208, p. 101). Argumenta-se que "o fundamento da democracia é o direito à vida" e que a "igualdade de dignidade de todos os seres humanos" é uma condição indispensável. Questionam-se os pressupostos do movimento pelo direito de decidir: "o aborto anuncia uma concepção de liberdade que exalta o indivíduo que se pode fazer ouvir. [...] Não se pode admitir a eliminação de uma pessoa inocente em nenhum caso" ( $\mathbb{S}$ 209 , p. 102, grifo original). O documento propōe a resistência dos profissionais de saúde que: "têm também o direito e o dever de se opor ao aborto, inclusive por meio da objeção de consciência e da recusa de obediência” (\$212, p. 103). Critica-se a sociedade que aceita uma "cultura da qualidade de vida, com critérios, subjetivos, materialistas e hedonistas, em substituição à sacralidade da vida, e que rejeita o sentido de qualquer sofrimento" $(\$ 213$, p. 103). Salta aos olhos o acionamento do discurso dos direitos humanos e da dignidade da pessoa com respeito ao feto e ao embrião. Nesse sentido, incitam-se os profissionais de saúde à resistência ao aborto, invocando sua consciência, reação fundamentada tanto biblicamente, como pelo discurso da cidadania e dos direitos humanos. A "sacralidade da vida" é o cerne do argumento contra a possibilidade de escolha, identificada a valores subjetivistas, materialistas e hedonistas. Os conceitos de subjetivismo, materialismo e hedonismo são reportados como categorias acusatórias, mas identificados por antropólogos como características da cosmologia moderna (cf. Duarte et al., 2006; Duarte, 2005) e do naturalismo. Entende-se por subjetivismo a preeminência da representação de uma escolha pessoal do sujeito, de uma presumida liberdade individual (Duarte $e t$ al., 2006, p. 18). Ainda com respeito à inadmissibilidade de qualquer tipo de aborto, vale recordar 
a análise de Boltanski (2004) sobre suas dimensões antropológicas: é reprovado na teoria e tolerado na prática, pertencendo ao domínio do oficioso; é raramente representado, a despeito de conhecido, o que evidencia seu caráter clandestino.

\section{O estatuto do embriāo e sua autonomia}

Ainda nessa seção IV, afirma-se a autonomia do embrião e sua condição de pessoa com base na biologia e, por consequência, no direito: "desde a fecundação até a morte, os processos vitais acontecem de forma interna, contínua, coordenada e gradual. $\mathrm{O}$ zigoto é um sujeito individual da espécie humana com possibilidade de desenvolvimento. Sendo um bem em si, deve ser respeitado no plano ético e protegido no plano jurídico, qualquer que tenha sido a sua origem” (\$214, pp. 103ss, grifo original). O embriāo humano "já é uma pessoa atual em seu ser” (\$214, p. 104). A proposta de "promoção humana como um processo integral, que considera a pessoa em todas as dimensões" (\$251, p. 116) está direcionada para o debate sobre reprodução e a defesa do embriāo humano. A construção do feto como um indivíduo em seu próprio direito é característica da biologização da retórica antiaborto (Franklin, 1991). Esse processo precedeu o debate sobre o estatuto do embrião de laboratório, no qual o embrião extracorporal gerado por fertilização in vitro aparece a título de nova figura de pessoa, um ente legal e social (Strathern, 1992). Segundo Salem (1997), a caracterização do embrião como pessoa, com base em critérios biológicos, oculta relações sociais, particularmente as de parentesco, no caso a relação com a gestante, representando-o em termos do ideal de indivíduo. Os valores naturalistas na descrição de embriōes e fetos como seres humanos essenciais em termos biológicos - conforme se vê na expressão que alega o caráter de sujeito individual da espécie humana ao zigoto, desde a fecundação até a morte - integram a cosmologia ocidental moderna, tornando-se uma poderosa arma na retórica pró-vida apresentada no texto-base. Quanto ao argumento do zigoto como bem em si, Machado (2008) questiona a defesa sem relativização deste "bem" pelos movimentos pró-vida, ao ressalvar que o embrião só se torna pessoa após o nascimento, antes disso sendo dotado de expectativa de direitos. Segundo a autora, os direitos atribuídos à pessoa são bens jurídicos; a noção de pessoa sempre é jurídica e o direito à vida está subordinado ao direito da pessoa. Novamente, voltamos à questão se o embrião ou o feto é uma pessoa independentemente de seu contexto. A análise do manual sugere a aproximação entre a concepção de vida, ou de direito à vida, como bem jurídico, e a noção da vida como dom de Deus na religião judaico-cristã (Franklin, 1995).

\section{Considerações finais}

Giumbelli (2003) defende a tese de que, em certos contextos, política e religião se constituem mutuamente. Incluir o Estado e a relação constitutiva entre política e religião como princípios analíticos esbarra em ideias consagradas acerca do lugar da religião na modernidade - separação entre Igreja e Estado e marginalização social da religião, tópicos estes abordados pela teoria da secularização. No Brasil, é patente a atuação da Igreja Católica em várias arenas da esfera pública, sobretudo quando o problema envolve reprodução e sexualidade. Giumbelli alerta que certas formas de presença da religião no espaço público não foram construídas se opondo à secularização, mas ocorreram "no interior da ordem jurídica encimada por um Estado comprometido com os princípios da laicidade" (2008, p. 81). Secularismo ou laicidade são princípios que integram o projeto da modernidade ocidental. Produzem moralidades distintivas, o que pode ser fruto de tensão entre o par indissociável "secular"/"religioso". Com respeito à Igreja Católica, Berger constatou essa tensão nos processos de secularização e dessecularização $(1985,2001)$.

O magistério da Igreja Católica tem se posicionado de maneira agressiva nas disputas públicas referentes ao aborto e ao estatuto do embrião humano. A ênfase na individualidade e na singularidade desse ente, o que faria dele uma pessoa ou até mesmo um cidadão, remete às primeiras reflexões de Durkheim sobre o individualismo como religião. $\mathrm{O}$ embrião é sagrado independentemente de seu contexto, do mesmo modo que o indivíduo seria o cerne da reli- 
gião moderna centrada nos direitos do ser humano e do cidadão, na qual se cultua o ser humano em abstrato (Durkheim, 1970; Dumont, 1992).

Para afirmar sua posição, a Igreja precisa de adesão no espaço público; para tanto, seus representantes se valem do uso da linguagem. Cunha (2007) destaca as guerrilhas semânticas de vocabulário travadas nas audiências públicas sobre o aborto a fim de situar o estatuto de embrião e feto. $\mathrm{O}$ manual da Campanha da Fraternidade contém diversos exemplos nesse sentido. Diniz (2001) aponta a variedade de termos e expressões que representam estratégias diferenciadas de embaraçar o diálogo nos debates sobre aborto no Congresso Nacional. A linguagem, segundo Cunha, produz força simbólica. Considerando a existência de um mercado linguístico na esfera pública (Bourdieu, 1996), as condiçôes de enunciação obrigam os militantes de distintas áreas a apelar não só para o discurso biológico (Luna, 2002), mas também para o discurso jurídico (Luna, 2008; Gomes e Menezes, 2008, Machado, 2008), para ganhar posição na disputa sobre verdades. Se os cientistas favoráveis ao uso de embrião em pesquisa chamamno de blastocisto (Luna, 2007a), os representantes oficiais da Igreja Católica e de movimentos pró-vida o chamarão de criança (não nascida), ou mesmo de cidadão (cf. Luna, 2007a; Cesarino, 2006; Gomes, 2009). Portanto, a luta da Igreja é impedir a ampliação dos permissivos para o aborto legal e garantir o estatuto de pessoa plena ao embrião de laboratório.

O Manual da Campanha da Fraternidade de 2008 é um claro exemplo acerca da discussão proposta por Boltanski sobre as fronteiras da humanidade referentes à condição fetal. As novas tecnologias para a visualização fetal na obstetrícia, para geração de embriōes fora do corpo, para a medicina fetal com cirurgias dentro do útero, e os dispositivos jurídicos para regular o estatuto do nascituro no útero e dos embriōes de laboratório, enfim, esse conjunto de tecnologias médicas e jurídicas tornou fetos e embriōes entes mais acessíveis, permitindo sua inserção na sociedade de formas inauditas (Boltanski, 2004). Esse processo oculta a relação do feto com a mulher da qual depende seu desenvolvimento. O texto-base da campanha aciona referentes biológicos para atestar a condição de pessoa do embriáo, não importando se dentro ou fora do corpo materno, e da situação daquela que poderia portálo. A escolha de marcos biológicos em termos de características essenciais da vida e da pessoa (Salem, 1997) está associada a uma conjunção de valores teológicos ou filosóficos com respeito à sacralidade da vida humana e desses "sujeitos" na qualidade de indivíduos dotados de dignidade intrínseca. Valores religiosos da vida como dom divino são laicizados, e a própria noção de vida desliza entre diversos discursos que transcendem o referente biológico. Nas temáticas aqui analisadas sobre a noção de pessoa, o início da vida e o direito à vida, o estatuto do embriáo e do feto e sua autonomia como sujeito tópicos relacionados com o aborto, a produção de embriôes in vitro e a possibilidade de seu uso em pesquisa -, os aspectos laicos e religiosos estão profundamente imbricados. A retórica da dignidade da pessoa e dos direitos humanos atribuídos a fetos e embrióes ecoa valores vinculados à sacralidade da vida como dom de Deus, os quais são traduzidos em termos jurídicos segundo a configuração laica na noção da vida como bem. O que é sagrado na religião se traduz em interdito no direito: fetos e embrióes teriam o direito inviolável à vida desde a concepção. Diante de realidades "sagradas", não há a possibilidade de escolha, ao contrário do que propõem os movimentos que afirmam a autonomia do sujeito quanto ao direito de decidir. Grupos com interesses tão distintos se apoiam na mesma configuração individualista de valores e consideram intocáveis os direitos dos sujeitos, mas a condição de sujeito é atribuída diferencialmente. A plenitude da condição de pessoa humana seria estabelecida desde a fecundação, conforme defende a Igreja Católica e segmentos alinhados aos movimentos pró-vida? $\mathrm{Ou}$ haveria uma hierarquização de direitos em conflito, segundo afirma Machado (2008)?

Embora a retórica da CNBB seja a da defesa da vida em sua integralidade, a análise do manual da CF-2008 explicita a ênfase no estágio de desenvolvimento anterior ao nascimento. Usam-se dados da biologia para fundamentar tal posição, sobretudo o argumento de essencialismo genético da individualidade do zigoto a partir da fecundação, além da autonomia de seu processo de desenvolvimento (Strathern, 1992; Salem 1997), independentemente do contexto. Esta é a representação da pessoa humana 
como indivíduo, valor estruturante da cosmologia ocidental moderna, o sujeito de direitos e detentor de liberdades. O conceito filosófico de dignidade da pessoa enunciado por Kant é sobreposto a interpretações bíblicas e teológicas. O embrião seria depositário de todos os direitos, o que contrasta com a abordagem sobre a mulher como aquela que tem vocação à maternidade e meio para o desenvolvimento da outra "pessoa de verdade". Tal perspectiva sobre a vida humana é anunciada explicitamente no manual para confrontar tentativas de enfocar o aborto como problema de saúde pública por parte do Ministério da Saúde e da Secretaria Especial de Políticas para as Mulheres e de permitir o uso de embrióes congelados ou inviáveis em pesquisa conforme estabelecido pela Lei de Biossegurança e confirmado pelo julgamento da ADI 3510 no Supremo Tribunal Federal. O conceito de "vida" desliza entre o referente do processo biológico para concepçōes metafísicas do valor da dignidade humana e dignidade como dom divino.

\section{Notas}

1 A discussão pública sobre o uso de embriões para extração de células-tronco é iniciada no Legislativo em 2003, com os debates no Congresso Nacional sobre a Lei de Biossegurança (Cesarino, 2006). Na Secretaria Especial de Políticas para as Mulheres, o marco a esse respeito ocorreu na I Conferência Nacional de Políticas para as Mulheres em 2004. No Ministério da Saúde, a aprovação da Norma Técnica de Atenção aos Agravos da Violência Sexual contra Mulheres e Adolescentes, em 1998, e sua reedição, em 2005, como Norma de Prevenção e Tratamento dos Agravos Resultantes da Violência Sexual contra Mulheres e Adolescentes remetem ao problema do aborto legal. A norma técnica de atenção humanizada ao abortamento (2004) vem na mesma direção, e abrange os casos de aborto clandestino (cf. Cunha, 2007).

2 Disponível em <http://www.cnbb.org.br/ns/modules/mastop_publish/?tac=Pastorais_e_Organismos $>$, consultado em 10 abr. 2009.

3 Para uma análise da relação entre as pastorais sociais da Igreja Católica, as políticas públicas e o discurso da caridade, cf. Silva (2006)

4 Os eventos referidos são o VI Encontro Mundial de Famílias no México em 2009 e o XII Congres- so Nacional da Pastoral Familiar, respectivamente. Ver <http://www.cnbb.org.br/ns/modules/mastop_ publish//?tac=55>, consultado em 10 abr. 2009.

5 O autor, ex-procurador Cláudio Fonteles, foi designado de "franciscano que recrutou cientistas ligados à Igreja Católica para deporem" (Rafael Garcia e Laura Capriglione, "Fonteles acusa cientista de ter viés judaico”. Folha de S. Paulo, 21 abr. 2007, p. A 20).

6 Silvana Freitas. "Juiz católico adia decisão sobre embrião: ministro Menezes Direito pede vista de processo no Supremo que decidirá se pesquisa com célula-tronco pode continuar”. Folha de S. Paulo, 6 mar. 2008, p. A20.

7 O ministro do STF, Carlos Alberto Menezes Direito, foi conselheiro da União de Juristas Católicos do Estado do Rio de Janeiro (Ujucarj), cf. a diretoria na página da Ujucarj, disponível em <http://juristascatolicosrj.org/diretoria.html>, consultado em 5 abr. 2009. Existem associaçôes desse tipo em diversos estados: a Associação de Juristas Católicos do Rio Grande do Sul (AJC-RS), disponível em <http://ajcrs.org/>; União de Juristas Católicos do Espírito Santo, cf. página da OAB desse estado (Oabes), disponível em <http:// www.oabes.org.br/detalhe_noticia.asp?id=551891>; União de Juristas Católicos de Pernambuco, cujo endereço consta na página da Arquidiocese de Olinda e Recife, disponível em <http://www.arquidioceseolindarecife.org.br/movimentos $2 . h t m>$; a notícia da criação da União dos Juristas Católicos da Arquidiocese de Goiânia foi veiculada no portal da CNBB, disponível em <http://www.cnbb.org.br/ns/modules/news/ article.php? storyid $=689 \&$ keywords $=$ juristas $>$. A consulta em todas essas páginas ocorreu em 5 abr. 2009.

8 Carolina Brígido e Ciça Guedes. "A dor de ter um filho e não levá-lo para casa: Em Teresópolis, duas mulheres não conseguiram autorização para interromper gravidez de bebês sem cérebro". O Globo, 8 jul. 2004, p. 5.

9 Compareceram o ministro José Gomes Temporão e a ministra Nilcéa Freire da Secretaria Especial de Políticas para as Mulheres (presidente do CNDM). Da sessão sobre representantes de religiōes participaram a CNBB (com o padre assessor nacional da Comissão Episcopal para a Vida e a Família, e o presidente da Associação de Juristas Católicos da Arquidiocese do Rio de Janeiro), da Igreja Universal do Reino de Deus, da Associação Nacional Pró-Vida e Pró-Família, da ONG feminista Católicas pelo Direito de Decidir, e da Associação Médico-Espírita do Brasil. Cf. no Portal do STF. Disponível em <http://www.stf.jus.br/ portal/cms/verTexto.asp?servico=processoAudienciaP ublicaAdpf54\#>, consultado em 7 abr. 2009. 
10 Do lado favorável à ADPF 54 e à pesquisa com embrióes, compareceu Debora Diniz da ONG Anis - Instituto de Bioética, Direitos Humanos e Gênero e, do lado oposto, Lenise Aparecida Martins Garcia presidente do "Movimento Nacional de Cidadania em Defesa da Vida - Brasil sem Aborto", Rodolfo Acatauassú Nunes presidente da Associação Nacional Pró-Vida e Pró-Família e a médica Elizabeth Kipman Cerqueira. Os três últimos foram indicados pela CNBB para a audiência referente à ADI 3.510.

11 Cunha (2007) fez etnografia da formulação da proposta pela comissão tripartite e da audiência pública.

12 A ministra Nilcéa Freire entregou o projeto elaborado ao presidente da Comissão de Seguridade Social e Família da Câmara dos Deputados. Cf. "Nilcéa entrega proposta final da comissão tripartite ao presidente da Comissão de Seguridade Social e Família”. Secretaria Especial de Políticas para as Mulheres. Brasília, 29 set. 2005. Disponível em <http://200.130.7.5/spmu/legislacao/comissao_gravidez/comissao_28_09.htm>, consultado em 22 mar. 2009. A proposta normativa da Comissão de revisão da legislação punitiva que trata da interrupção voluntária da gravidez está disponível em <http://200.130.7.5/spmu/docs/proposta $\% 20$ normativa.pdf>, consultado em 22 mar. 2009.

13 A revisão da norma técnica é anterior à posse de José Gomes Temporão como ministro em março de 2007, o que sugere que a revisão sobre a legislação do aborto não é uma peculiaridade do atual ministro, mas uma política desse ministério e da SPM no atual governo. O estudo promovido pelo Ministério da Saúde está disponível em forma do relatório final e de cartilhas. Cf. Brasil (2009, 2008).

14 Padre Luiz Antônio Bento (entrevista a Catarina Alencastro). "O Estado tem feito uma política de aborto". O Globo, 22 mar. 2009, p. 12.

15 Temas: CF-1974 - "Reconstruir a vida"; CF-1984 "Fraternidade e vida". Lemas: CF-1984 - "Para que todos tenham vida"; CF-1998 - "A serviço da vida e da esperança”; CF-2001 - "Vida sim, drogas não"; CF-2003 "Vida, dignidade e esperança”; CF-2004 - "Água, fonte de vida"; CF-2007 - "Vida e missão neste chão".

16 A autoria do hino é do Pe. José Antônio de Oliveira e da oração é de Dom Dimas Lara Barbosa (Bispo Auxiliar de São Sebastião do Rio de Janeiro e Secretário Geral da CNBB).

17 Em Duarte et al. (2009) investiga-se a atuação de parlamentares religiosos na tramitação de projetos de lei que envolvem aborto, eutanásia, parceria civil (casamento gay) e combate à homofobia.
18 A mudança epistêmica ocorrida no Iluminismo quando se toma a Natureza como fundamento da realidade e base das prescrições de ordem social (Laqueur, 1992) propiciou o pensamento naturalista.

\section{BIBLIOGRAFIA}

ANGELOZZI, Gilberto Aparecido. (2008), "Religião e poder na América Latina: um breve estudo sobre religião como forma de controle social no Brasil", in Maria Teresa Toríbio Brittes Lemos (org.), América Latina: identidades em construção - das sociedades tradicionais à globalização. Rio de Janeiro, 7Letras, pp. 69-82.

ANJOS, Gabriele. (2007), "Maternidade, cuidados do corpo e 'civilização' na Pastoral da Criança”. Estudos Feministas, 15 (1): 27-44.

BERGER, Peter L. (1985), O dossel sagrado: elementos para uma teoria sociológica da religião. São Paulo, Paulus. . (2001), "A dessecularização do mundo: uma visão global”. Religiāo \& Sociedade, 21 (1): 9-23.

BIRMAN, Patrícia. (2003), "Introdução", in Patrícia Birman (org.), Religião e espaço público, São Paulo, Attar, pp. 11-21.

BOLTANSKI, Luc. (2004), La condition foetale: une sociologie de l'engendrement et de l'avortement. Paris, Gallimard.

BOURDIEU, Pierre. (1996), A economia das trocas lingüisticas: o que falar quer dizer. São Paulo, Edusp.

BRASIL. Ministério da Saúde/Secretaria de Ciência, Tecnologia e Insumos Estratégicos. (2008), "20 anos de pesquisa sobre aborto no Brasil". Brasília, Ministério da Saúde (série B. Textos Básicos em Saúde). Disponível em <http:// portal.saude.gov.br/portal/arquivos/pdf/aborto.pdf>, consultado em 25 mar. 2009. . (2009), "Aborto e saúde pública: 20 anos”. Brasília: Ministério da Saúde (série B. Textos Básicos em Saúde). Disponível em <http://bvsms.saude.gov.br/bvs/publicacoes/ livro_aborto.pdf>, consultado em 9 abr. 2009.

CAVALCANTE, Alcilene \& XAVIER, Dulce. (2006), Em defesa da vida: aborto e direitos hu- 
manos. São Paulo, Católicas pelo Direito de Decidir.

CESARINO, Letícia Maria Costa da Nóbrega. (2006), Acendendo as luzes da ciência para iluminar o caminho do progresso: uma análise simétrica de Lei de Biossegurança brasileira. Brasília, dissertação de mestrado em Antropologia Social, PPGAS-UnB.

CONFERENCIA NACIONAL DOS BISPOS DO BRASIL. (2008), Campanha da Fraternidade 2008: Manual. São Paulo, Salesiana.

CUNHA, Anna Lúcia Santos da. (2007), Pessoa e direito, corpo e ciência: negociando significados e preceitos cosmológicos em torno da legalização do aborto. Brasília, dissertação de mestrado em Antropologia Social, PPGAS-UnB.

DINIZ, Debora. (2001), "Um espelho das moralidades: o debate sobre o aborto no Congresso Nacional brasileiro”. Série Anis, 23. Brasília, Letras Livres.

DUARTE, Luiz Fernando Dias (2005), "Ethos religioso e jusficação religiosa. Negociações da reprodução na sociedade brasileira", in Maria Luiza Heilborn, Luiz Fernando Dias Duarte, Clarice Peixoto e Myriam Lins de Barros (orgs.), Sexualidade, familia e ethos religioso, Rio de Janeiro, Garamond, pp. 137-175.

DUARTE, Luiz Fernando Dias; GOMES, Edlaine C.; JABOR, Juliana \& LUNA, Naara. (2006), "Família, reprodução e ethos religioso: subjetivismo e naturalismo como valores estruturantes”, in L. F. D. Duarte, Maria Luiza Heilborn, Myriam Lins de Barros e Clarice Peixoto (orgs.), Família e religiāo, Rio de Janeiro, Contracapa, pp. 15-49.

DUARTE, L. F. D.; GOMES, E. de C.; MENEZES, R. A. \& NATIVIDADE, M. (2009), Valores religiosos e legislação no Brasil: a tramitação de projetos de lei sobre temas morais controversos. Rio de Janeiro, Garamond/Faperj.

DUMONT, Louis. (1992), Ensaios sobre o individualismo: uma perspectiva antropológica sobre a ideologia moderna. Lisboa, Dom Quixote.

DURKHEIM, Émile. (1970), "L'individualisme et les intellectuels", in , La science sociale et l'action, Paris, Presses Universitaires de France, pp. 261-278.
FAGOT-LARGEAUT, Anne. (2004), "Embriōes, células-tronco e terapias celulares: questões filosóficas e antropológicas”. Estudos Avançados, 18 (51): 227-245.

FERNANDES, Maíra Costa. (2007), "Interrupção de gravidez de feto anencefálico: uma análise constitucional", in Daniel Sarmento e Flávia Piovesan (orgs.), Nos limites da vida: aborto, clonagem humana, eutanásia sob a perspectiva dos direitos humanos. Rio de Janeiro, Lumen Júris, pp. 111-158.

FRANKLIN, Sarah. (1995), "Life", in W. Reich (org.), Encyclopedia of bioethics, Nova York, MacMillan pp. 1345-1351.

(1991), "Fetal fascinations: new dimensions to the medical-scientific construction of fetal personhood", in S. Franklin, C. Lury e J. Stacey (eds.), Off-centre: feminism and cultural studies, Lancaster, HarperCollins Publishers, pp. 190-205.

GIUMBELLI, Emerson. (2003), "O 'chute na Santa': blasfêmia e pluralismo religioso no Brasil", in Patrícia Birman (org.), Religião e espaço público, São Paulo, Attar, pp. 169-199. . (2008), "A presença do religioso no espaço público: modalidades no Brasil”. Religião \& Sociedade, 28 (2): 80-101.

GOMES, Edlaine de Campos. (2009), "A religião em discurso: a retórica parlamentar sobre o aborto", in L. F. D. Duarte; E. de C. Gomes; R. A. Menezes e M. Natividade (orgs.), Valores religiosos e legislação no Brasil: a tramitação de projetos de lei sobre temas morais controversos. Rio de Janeiro, Garamond/Faperj, pp. 45-70.

GOMES, Edlaine de Campos \& MENEZES, Rachel Aisengart. (2008), "Aborto e eutanásia: dilemas contemporâneos sobre os limites da vida”. Physis: Revista de Saúde Coletiva, 17 (1): 77-103.

GOMES, Romeu. (1994), “A análise de dados em pesquisa qualitativa", in Maria Cecília de Souza Minayo (org.), Pesquisa social: teoria método e criatividade, Petrópolis, Vozes, pp. 67-80.

HURST, Jane. (2000), Uma história não contada: a história das idéias sobre o aborto na Igreja Católica. São Paulo, Católicas pelo Direito de Decidir. 
KALSING, Vera Simone Schaefer. (2002), "O debate do aborto: a votação do aborto legal no Rio Grande do Sul". Cadernos Pagu, 19: 279-314.

LAQUEUR, Thomas. (1992), Making sex: body and gender from the greeks to Freud. Cambridge/Londres, Harvard University Press.

LUNA, Naara. (2002), "As novas tecnologias reprodutivas e o estatuto do embrião: um discurso do magistério da Igreja Católica sobre a natureza". Gênero, 3 (1): 83-100.

LUNA, Naara. (2007a), "Embriōes no Supremo: ética, religião e ciência no poder público". Trabalho apresentado no $31^{\circ}$ Encontro Anual da Anpocs. Caxambu. Disponível em <http://201.48.149.89/anpocs/ arquivos/7_11_2007_18_35_48.pdf>, consultado em 30 nov. 2007.

(2007b), "A personalização do embriāo humano: da transcendência na Biologia". Mana: Estudos de Antropologia Social, 13 (2): 411-440.

(2008), "Células-tronco: novas formas de vida emergentes e a concepção de pessoa no debate público". Trabalho apresentado no $32^{\circ}$ Encontro Anual da Anpocs. Caxambu. Disponível em <http://200.152.208.135/ anpocs/trab/adm/impressao_gt.php?id_ grupo $=45 \&$ publico $=S>$, consultado em 31 out. 2008.

MACHADO, Lia Zanotta. (2008), "Os novos contextos e os novos termos do debate contemporâneo sobre o aborto: a questão de gênero e o impacto social das novas narrativas biológicas, jurídicas e religiosas". Série Antropologia, 419.

MELO, Jacira. (1997), "A polêmica do aborto na imprensa”. Estudos Feministas, 5 (2): 406-412.

MENEZES, Rachel Aisengart. (2009) "Projetos de lei em torno da eutanásia: entre poder médico, autonomia e valores religiosos", in L. F. D. Duarte; E. de C. Gomes; R. A. Menezes e M. Natividade (orgs.), Valores religiosos e legislação no Brasil: a tramitação de projetos de lei sobre temas morais controversos. Rio de Janeiro, Garamond/ Faperj, pp. 101-122.

NATIVIDADE, Marcelo \& LOPES, Paulo Victor Leite. (2009), "Os direitos das pessoas GLBT e as respostas religiosas: da parceria civil à crimi- nalização da homofobia", in L. F. D. Duarte; E. de C. Gomes; R. A. Menezes e M. Natividade (orgs.), Valores religiosos e legislação no Brasil: a tramitação de projetos de lei sobre temas morais controversos. Rio de Janeiro, Garamond/Faperj, pp. 71-99.

PIERUCCI, Antônio Flávio de Oliveira. (1978), "Igreja: contradições e acomodação. Ideologia do clero católico sobre reprodução humana no Brasil". Caderno Cebrap, 30.

PROPOSTA NORMATIVA. "Minuta de substitutivo! Comissão de revisão da legislação punitiva que trata da interrupção voluntária da gravidez". Disponível em <http://200.130.7.5/ spmu/docs/proposta\%20normativa.pdf>, consultado em 22 mar. 2009.

ROCHA, Maria Isabel. (1996), "A questão do aborto no Brasil". Estudos Feministas, 4 (2): 381-398.

ROSADO-NUNES, Maria José. (2002), "Catolicismo e direitos da mulher como direitos humanos". Concilium, 298: 55-69.

SALEM, Tania. (1997), "As novas tecnologias reprodutivas: o estatuto do embrião e a noção de pessoa". Mana, 3 (1): 75-94.

SANTIN, Myriam Aldana. (2000), Aborto legal: Igreja Católica e o Congresso Nacional. São Paulo, Católicas pelo Direito de Decidir.

SARMENTO, Daniel. (2006), "Legalização do aborto e Constituição", in Alcilene Cavalcante e Dulce Xavier, Em defesa da vida: aborto e direitos humanos, São Paulo, Católicas pelo Direito de Decidir, pp. 111-168.

SEFFNER, Fernando et al. (2008), "Respostas religiosas à Aids no Brasil: impressōes de pesquisa acerca da pastoral da DST/AIDS na Igreja Católica”. Ciências Sociais e Religiāo, 10 (10): 159-180.

SILVA, Claudia Neves da. (2006), "Igreja Católica, assistência social e caridade: aproximaçóes e divergências". Sociologias, 8 (15): 326-351.

STRATHERN, Marilyn. (1992), Reproducing the future: essays on anthropology, kinship and the new reproductive technologies. Manchester, Manchester University Press. 


\section{ABORTO E CÉLULAS-TRONCO EMBRIONÁRIAS NA CAMPANHA DA FRATERNIDADE: CIÊNCIA E ÉTICA NO ENSINO DA IGREJA}

\begin{abstract}
Naara Luna
Palavras-chave: Igreja Católica; Aborto; Células-tronco embrionárias; Vida.

Analisa-se o manual da Campanha da Fraternidade da CNBB de 2008, contextualizando a atuação da Igreja Católica na esfera pública. O tema "Fraternidade e defesa da vida” foi criado como reação não só ao esforço do Ministério da Saúde e da Secretaria Especial de Políticas para as Mulheres para recolocar o aborto como problema de saúde pública, e alterar a legislação, como também à geração de embriōes na reprodução assistida e uso de excedentes para produzir célulastronco. A pesquisa com células-tronco e o debate sobre a legalização do aborto são processos independentes liderados por atores sociais distintos (comunidade científica e movimento de mulheres). A Igreja é ator fundamental, aglutinando as controvérsias. O conceito de "vida" é chave na retórica que desliza entre o discurso científico e o religioso.
\end{abstract}

\section{ABORTION AND EMBRYONIC STEM CELLS IN THE FRATERNITY CAMPAIGN: SCIENCE AND ETHICS IN THE TEACHINGS OF THE CATHOLIC CHURCH}

\section{Naara Luna}

Keywords: Catholic Church; Abortion; Embryonic stem cells; Life.

The paper analyzes the handbook of the 2008 Fraternity Campaign, promoted by the National Conference of Brazilian Bishops (CNBB), and contextualizes the Catholic Church's action in the public sphere. The theme "Fraternity and defense of life" has emerged as a reaction to not only the effort by the Health Ministry and the Special Office of Women Policy to redefine abortion as a public health problem, and change legislation accordingly, but also to in vitro fertilization and the use of supernumerary embryos for stem cell generation. Stem cell research and the debate on abortion legalization are independent processes led by different social actors (the scientific community and women's movement). The Church is a leading and aggregating actor in this controversy. The concept of "life" is key to this debate, sliding between religious and scientific discourses.

\section{AVORTEMENT ET CELLULES SOUCHES EMBRYONNAIRES DANS LA CAMPAGNE DE LA FRATERNITÉ: SCIENCE ET ÉTHIQUE DANS L'ENSEIGNEMENT DE L'ÉGLISE}

\section{Naara Luna}

Mots-clés: Église catholique; Avortement; Cellules souches embryonnaires; Vie.

Cet article propose une analyse du manuel de la Campagne de la Fraternité de la CNBB (Conférence Nationale des Archevêques du Brésil) 2008, en contextualisant l'action de l'Église Catholique dans la sphère publique. Le thème "Fraternité et défense de la vie" a été créé comme une réaction non seulement à l'effort du Ministère de la Santé et du Secrétariat Spécial de Politiques pour les Femmes, pour remettre l'avortement comme un problème de santé publique et modifier la législation, ainsi que la génération des embryons dans la reproduction assistée et l'utilisation des excédents pour produire des cellules souches. La recherche avec des cellules souches et le débat sur la légalisation de l'avortement sont des processus indépendants menés par des acteurs sociaux distincts (la communauté scientifique et le mouvement de femmes). L'église est l'acteur fondamental, agglutinant les controverses. Le concept de «vie» est fondamental dans la rhétorique qui existe entre le discours scientifique et le discours religieux. 